\title{
Editorial
}

\author{
Back and Forth Between Sovereignty and Constitutionalism: \\ The Court of Justice's Constitutional Case Law
}

Sometimes the European Court of Justice hands down a judgment that causes surprise. From a constitutional point of view that was the case with the first judgment in Kadi, and most recently its judgment in M.A.S. and M.B, also known as Taricco bis. Many of us would not dare to bet that the Court would follow Advocate General Poiares Maduro in Kadi; in Taricco bis many thought it would not significantly diverge from the opinion of Advocate General Bot and from the earlier decision in Taricco I. Why do European Court of Justice judgments like these come as a surprise? Let us first look at these two examples and delve into the broader constitutional nature of the Court's case law, which may explain the surprise.

\section{SURPRISING JUDGMENTS}

Kadi I and Taricco bis are very different judgments, if only because of the difference between the respective subject matters of international sanctions in the context of the combatting of terrorism and of intertemporal aspects of the principle of legality in criminal matters. In Kadi the effect of EU implementing measures of UN Security Council resolutions that are binding erga omnes under Chapter VII and Article 103 of the UN Charter was at stake. As we all know, the EU measures were assessed in light of the principle of the binding nature of public international law under EU law. And significantly, the Court found that relevant EU law implying those UN resolutions' bindingness 'cannot be understood to authorise any derogation from the principles of liberty, democracy and respect for human rights and fundamental freedoms enshrined in Article 6(1) EU [now Article $2 \mathrm{EU}]$ as a foundation of the Union'. ${ }^{1}$ This was pivotal within the reasoning of the judgment.

\footnotetext{
${ }^{1}$ ECJ 3 September 2008, Joined Cases 402/05P and 415/05P, Kadi I, para. 303.
} 
In Taricco bis we are dealing with a particular Italian understanding of the principle of legality in criminal law. The fuller details of the case and the legal rules and principles involved, in both Italian law and under EU law as well as of the particular context of the cases adjudicated by the European Court of Justice, are more adequately described in the case note by Piccirilli in this issue. ${ }^{2} \mathrm{~A}$ crucial point is that in the Corte costituzionale's understanding of the principle of legality in criminal matters enshrined in Article 25(2) of the Italian Constitution, various particular aspects apply to the statute of limitations. The statute of limitations is not purely procedural but substantive in nature, so elements of the legality principle such as the lex certa and the nullum crimen sine lege praevia principles apply to it. This understanding of legality in criminal matters belongs, so the Corte costituzionale, 'beyond any doubt' to 'the supreme principles of the Italian constitutional order and the inalienable rights of the human person' ${ }^{3}$ which under established constitutional case law of the Corte costituzionale ${ }^{4}-$ must be respected by EU law; if EU law does not do so, EU law cannot apply in Italy.

The problem was that according to the Court of Justice in Taricco [I] Italian courts had to disapply the Italian statute of limitations as it was judged to be in conflict with Article 325 TFEU. It found that the relevant legislation would have to be disapplied if it prevents 'the imposition of effective and dissuasive penalties in a significant number of cases of serious fraud affecting the financial interests of the European Union, or provides for longer limitation periods in respect of cases of fraud affecting the financial interests of the Member State concerned than in respect of those affecting the financial interests of the European Union'. 5 The European Court of Justice found that this obligation to disapply the act did not conflict with Articles 49 Charter and 7 ECHR, as in the Court's view it was outside the scope of the principle of legality in criminal matters: ' $\mathrm{I}] \mathrm{t}$ would in no way lead to a conviction of the accused for an act or omission which did not constitute a criminal offence under national law at the time when it was committed (...) nor to the application of a penalty which, at that time, was not laid down by national law'. ${ }^{6}$ It specified explicitly that the Italian courts, if they were to find the conditions for unlawfulness fulfilled, would have to ensure the full effect of this obligation under Article 325 TFEU, without awaiting legislative measures 'or any other constitutional procedure'?

\footnotetext{
${ }^{2}$ G. Piccirilli, The "Taricco Saga": The Italian Constitutional Court continues its European Journey, 14(4) EuConst (2018) p. 814.

${ }^{3}$ Ordinanza N. 24, Anno 2017, Ritenuto in fatto e considerato in diritto, section 2, second paragraph: '... non vi è dubbio...'.

${ }^{4}$ Corte costituzionale [Constitutional Court], 27 December 1973, Case no. 183/1973 (Frontini); Corte costituzionale [Constitutional Court], 21 April 1989, Case no. 232/1989 (Fragd).

${ }^{5}$ ECJ 8 September 2015, Case C-105/14, Taricco [I], para. 58.

${ }^{6}$ Ibid., para. 56.
} 
Without going into the detail, one can sense this would raise some Italian eyebrows as in their understanding the disapplication might amount to extending the statute of limitations in contravention of the principle of legality (as understood in Italy). And indeed the Corte costituzionale in its reference raised the issue that Taricco [I] might have to force Italian courts to act in contravention of the principle of legality in criminal matters that belongs to 'the supreme principles of the Italian constitutional order and the inalienable rights of the human person', and to its constitutional identity.

In Taricco bis the Court of Justice took a very different approach to the Charter and ECHR from the one it had taken in the earlier Taricco [I] case, and judged that Italian courts are indeed allowed to bring statute of limitation rules under the principle of legality in criminal law that must be observed also in a context that involves Union law. This time it held that the criminal law requirements of foreseeability, precision and non-retroactivity inherent in the principle of legality must be observed by member states, and said this follows from Article 49 of the Charter, ${ }^{8}$ the constitutional traditions common to the member states, ${ }^{9}$ and Article 7 ECHR. ${ }^{10}$ It found this to entail that in the Italian legal system courts are not obliged to follow Taricco [I] and may even be precluded from following it if the Taricco I rule leads to a situation of uncertainty in the Italian legal system as regards the applicable limitation rules, or if it concerns acts committed before Taricco [I] was delivered. ${ }^{11}$ If the Italian courts were not able to apply Taricco [I], the obligation under Article 325 TFEU would shift from the courts to the legislature, which would have to take the required measures. $^{12}$

Despite differences, Kadi $I$ and Taricco bis have in common that constitutional values play a crucial role in coming to their respective conclusions. And this is precisely what could not be expected: evidently, the intuition is that certain constitutional values - values associated with 'constitutionalism' as explained below - cannot be expected to play the most decisive role in the Court of Justice's case law. This gives food for thought. What is the approach we instead expect the Court of Justice to take in constitutional matters? And what does it mean for the nature of the constitutional case law of the Court if we do not really expect the Court to consider constitutionalist values decisive?

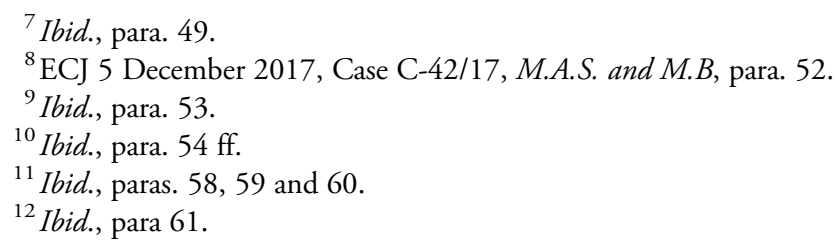




\section{CONSTITUTIONS: SETTLING SOVEREIGNTY}

Constitutions serve different objectives in different manners. An important objective of constitutions, different from the one that is nowadays associated with securing 'constitutionalism' and the 'rule of law', is to settle sovereignty issues. In Europe, from ancient Rome through the Middle Ages and early modernity, the lex regiae, acts of succession and similar documents, served to identify the sovereign and ascertain his ultimate authority. Sovereignty became the hallmark and decisional conflict rule for the Westphalian state: it asserts the predominant authority of the sovereign over subjects, and provides a rule for settling conflict whenever competing claims of authority might arise. Conflicts of laws emanating from different sources of authority can be settled by the use of sovereignty as essentially a criterion based on rank.

Ascertaining sovereignty as core objective marked the constitutional debate in much of $19^{\text {th }}$ century continental Europe, which was largely about the relationship between government and parliament, between the sovereignty of the monarch and her government and the sovereignty of the people. It was settled with the introduction of ministerial responsibility and issued into the general franchise (though in some countries women remained excluded from being able to vote and represent the voters) and pre-dominantly parliamentary systems of government as the standard in Europe.

Not least, sovereignty was a central issue in the 'constitutional' case law of the European Court of Justice in the early phase of so-called constitutionalisation of European law, in the context of the relations between Europe and its member states. It had to contend with the claims to sovereignty of the member states - or at least it evidently found it had to do so. And in the course of contending with the varying ways and strategies of member states with regard to their constitutional law and traditions regarding sovereignty and international law, it threatened to become itself infected with some of the language and logic of sovereignty, and did not escape from it entirely unscathed. ${ }^{13}$

Thus, in the landmark case of Van Gend \& Loos the European institutions were said to be endowed with 'sovereign rights'/droits souverains/ poteri sovranil Hoheitsrechte/soevereine rechten which were transferred (in the German version: übertragen) to them by the member states who were thus supposed to have limited 'their sovereign rights' (the English version), their Souveränitätsrechte ('rights pertaining to sovereignty' in the German version) or simply their soevereiniteit

\footnotetext{
${ }^{13}$ Without being able to elaborate on its implications, it must of course be mentioned that to its merit, the ECJ has always managed to avoid the ultimate consequence of fully sovereigntist approaches (sovereignty as suprema potestas), which is to speak of the European Community/Union's supremacy, contrary to the belief of many EU law textbook authors who understand the doctrine and principle of primacy of EU law as the doctrine and principle of 'supremacy'.
} 
('sovereignty' in the Dutch version) as such. ${ }^{14}$ The language of transfer of sovereign rights or sovereignty from member states to the EEC was subsequently used as justification for the primacy of European law over conflicting national law in Costa $v$ ENEL. In these judgments, sovereignty is considered to be a decisive non-zero sum game: the sovereignty that is taken away from member states has accrued to the EC and made it sovereign within the fields of its competence. This sovereignty gained by the European institutions is the justification for the legally binding operation of European law towards citizens in Van Gend en Loos; it is the justification for primacy of European law over national law as the solution of conflicts that might exist between European and member state law in Costa $v$ ENEL: the rights and powers of European institutions being predicated as 'sovereign' implied the direct effect of European law to the exclusion of claims of applicability of contrary national law.

This was axiomatic not merely in order to secure the functional priority of European law in the earliest stages of European integration, but remained central in the subsequent assertion of primacy over constitutional law, principles and values in Internationale Handelsgesellschaft and Simmenthal II: directly effective EU law has priority over any national law, whatever the latter's constitutional rank or status. Remarkably, the overriding principle of primacy of EU law over national law as the resolution of conflicts of laws, has also remained decisive long after the period of 'constitutionalisation', and long after EU law's primacy over national parliamentary legislation had become generally accepted by national courts. Or perhaps it should be said: it re-emerged with an edge as far as the priority of any type of EU law over any type of national law is concerned, in the course of the Skouris court after having lain dormant for a few decades. Among notable examples has been the European Court of Justice's judgment in Melloni, ${ }^{15}$ in which even a not-directly effective norm of secondary EU law - which for its efficacy is therefore dependent on implementation and transposition in national law - was granted priority over conflicting directly effective constitutional norms of Spain in the field of fundamental rights. The ultimate justification for this priority was the primacy of EU law; ${ }^{16}$ the substantive nature of the norms that were set aside played no role whatsoever. Another example is Opinion 2/13 in which again primacy of EU law and the 'autonomy' of the European Court of

${ }^{14}$ ECJ 5 February 1963, Case 26/62, Van Gend en Loos, French version p. 23-24; Italian version, p. 22-23; German version p. 24-25; Dutch p. 23; English p. 12.

15 'A Constitutional Moment: Acceding to the ECHR (Or Not)', 11(1) EuConst (2015) p. 2.

${ }^{16}$ It relied on the argument of the uniformity and effectiveness of EU law to motivate primacy, but ironically did so precisely where the text of Art. 53 EU Charter of Fundamental Rights seemed to allow for diversity. See L.F.M. Besselink, 'Parameters of Constitutional Conflict after Melloni', 39(4) European Law Review (2014) p. 531, available at <ssrn.com/abstract $=2345143>$, visited 27 October 2018. 
Justice - understood as the Supreme Court of the $\operatorname{Union}^{17}$ - were reason to refuse the proposed accession to the European Convention on Human Rights that is mandatory under Article 6(2) TEU. ${ }^{18}$ Whatever the merits of some other objections of the Court, on balance it can be said that even these were ultimately overshadowed by pure considerations of formal and absolute priority. It was the sovereignty of the EU, and more particularly that of the Court, which was decisive at the expense of the protection of rights of citizens. Priority at any price.

\section{Constitutionalism}

Modern constitutions in the Western world aim to solve conflicts and can do so on the basis of formal hierarchy, in particular in defining their positions towards other sources of power and authority. The history of constitutionalism, however, traces the very phenomenon of constitutions not merely to rules concerning the sovereign and his powers, but more in particular to the late medieval and early modern charters which specified the terms under which subjects owed obedience to the sovereign. This is where constitutional principles or the 'values' we associate with 'constitutionalism' enter into constitutional discourse.

It took a while but in the later 'constitutionalising' phase, the Court of Justice eventually allowed a place for such constitutional values in its case law, in the form of a measure of fundamental rights protection, but under the strict assertion of European law's absolute primacy and the subjugation of national constitutional values as irrelevant and potentially undermining the primacy of European law. ${ }^{19}$ This was before the days of the Maastricht Treaty, which founded the Union on the constitutional principles and values common to the member states (Article F), and well before the Treaties of Amsterdam and Lisbon which articulated ever more precisely that the Union is to respect the constitutional identity of member states. ${ }^{20}$ It was only after the establishment of the Union on these constitutionalist principles, that sensitivity to fundamental constitutional values of a member state

${ }^{17}$ L.F.M. Besselink, 'The ECJ as the European "Supreme Court": Setting Aside Citizens' Rights for EU Law Supremacy', VerfBlog, 18 August 2014, <www.verfassungsblog.de/ecj-europeansupreme-court-setting-aside-citizens-rights-eu-law-supremacy >, visited 27 October 2018.

${ }^{18}$ ECJ 18 December 2014, Opinion 2/13.

${ }^{19}$ ECJ 17 December 1970, C-11/70, Internationale Handelsgesellschaft : 'The law stemming from the Treaty, an independent source of law, cannot because of its very nature be overridden by rules of national law, however framed, without being deprived of its character as Community law and without the legal basis of the Community itself being called in question. Therefore the validity of a Community measure or its effect within a member state cannot be affected by allegations that it runs counter to either fundamental rights as formulated by the Constitution of that state or the principles of its constitutional structure'.

${ }^{20}$ Thus reversing the Court's view expressed in Internationale Handelsgesellschaft. 
became evident. A classic case is Omega, ${ }^{21}$ in which a particular German understanding of the meaning of human dignity was considered a justifiable restriction to free movement, for the very importance it takes in the German Constitution. And sensitivity to the basis of the Union in the common constitutional values shared by the member states became evident in Kadis crucial reliance on the values of (now) Article 2 TEU as qualifying and conditioning the operation of otherwise binding public international law. ${ }^{22}$

\section{DYNAMICS}

What to make of these various tendencies, tendencies that can sometimes be reconciled only with difficulty? Let us distinguish the European Court of Justice and the national courts' perspectives.

The quasi-hierarchical turn in European Court of Justice case law was understandable when European law had to establish itself, in line with the objectives of overcoming the hubris of sovereignty that had led to an endemic state of war in Europe. At the same time it is paradoxical that the very process of creating a 'post-sovereign' Europe was achieved through European Court of Justice case law that crucially hinges on asserting sovereignty on the basis of the autonomy of the new European legal order. However that may be, the Court gradually came round to accept and eventually recognise the meaning and importance of constitutionalist values. But the combination of the two approaches, and the repeated recurrence of formal primacy as outweighing constitutionalist principles, as in Melloni, Winter Wetten ${ }^{23}$ and Opinion 2/13, makes the overall European Court of Justice approach at this moment somewhat confused and unpredictable when it comes to constitutional values: hence the surprise at the occasional more constitutionalist outcomes.

The member state courts have gradually turned away from the prominence of hierarchical notions of sovereignty. It is undoubtedly true that in most continental European constitutions the idea prevails that any legal norm ultimately derives its legal force from the fact that the constitution recognises or allows these norms to be operative within the relevant constitutional order. To the extent that one can say that thus all legal norms within the relevant order derive from the constitution, the constitution can be said to be superior to any other legal norm. When this is applied to conflicts that might arise between EU norms and national constitutional norms, and these conflicts are resolved by stating that the national norm for this reason precedes the EU norm, an hierarchical lex superior reasoning is

\footnotetext{
${ }^{21}$ ECJ 14 October 2004, Case C-36/02, Omega.

${ }^{22}$ See supra n. 1.

${ }^{23}$ ECJ 8 September 2010, Case C-409/06, Winter Wetten.
} 
applied. This, however, is in practice not any longer the only or even major manner in which such conflicts are resolved. Instead, most constitutional courts that are faced with a potential or actual collision of norms and affirm the priority of a national constitutional norm, do so on the basis of the substantive value of the national constitutional norm, and not primarily on the strictly formal hierarchy of norms (the lex superior principle). Constitutionalist concerns become predominant in the sense that the constitution is understood as the embodiment of values that are particularly cherished in the relevant public order; and it is these values that are taken to be decisive.

The paradox emerges that while national courts become more constitutionalist, the Court of Justice has tended to adhere to autonomy even in recent times, up to the point of barring constitutionally mandated accession to the European Convention on Human Rights: ${ }^{24}$ subjecting the Union and its institutions to the Convention stands in the way of autonomy and primacy, a view that only the Court and none of member states and other institutions shared. It seems as if only in case national courts insist on constitutional values such as the subjection of the exercise of public power by legislature, executive and courts to fundamental rights, the Court of Justice can sometimes be prompted to take such values seriously and let them prevail over Union law. This dynamic - taking its cue from national constitutional case law - remained implicit in Kadi I, because it did not involve a reference by a national court. But imagine what would have happened had $\mathrm{Mr}$ Kadi started proceedings in Germany, after the Court of Justice wanted to leave intact the Council Regulation copy pasting the freezing of his assets as called for by the UN resolutions. Would the Bundesverfassungsgericht have allowed the operation of that Union implementing regulation to go at the expense of the right of access to justice and the right to property as protected under the Grundgesetz? That is hard to imagine. There was more than a good chance that the disapplication of the relevant Union law in Germany would follow for reason of Union law infringing core rights that form part of Germany's constitutional identity. ${ }^{25}$ The Court of Justice must certainly have been aware of that when setting aside the Court of First Instance's judgment in Kadi I as well as annulling the relevant Council Regulation. Taricco bis, being a reconsideration of Taricco [I], was prompted by one of the rare references by the Corte costituzionale in which the latter made explicit that Taricco [I] could well be an infringement of core fundamental rights belonging to the constitutional identity of the Italian Republic, leading to the disapplication of Union law (a judgment of the Court of Justice!). In both cases the Court was aware or made aware of the consequences

\footnotetext{
${ }^{24}$ Art. 6(2) TEU.

${ }^{25}$ Technically, the constitutional identity argument might not yet be invoked by the $B V \operatorname{erf} G$ as it began linking core fundamental rights and constitutional identity more explicitly only later.
} 
that ignoring the relevant constitutional values would have. Somewhat paradoxically, in both cases insensitivity to the national constitutionalist concerns on the part of the Court of Justice would have meant that the primacy of Union law would be affected if the Court had based its reasoning on autonomy and primacy. Instead, in these cases it therefore based its judgments on constitutional principles and values that outweighed considerations of autonomy and primacy.

\section{Conclusion}

What was just said about Kadi and Taricco bis, applies mutatis mutandis also to cases like Gaal, ${ }^{26}$ Omega, Sayn Wittgenstein and the line of case law on data protection following after Schecke. ${ }^{27}$ It is national constitutional case law and the promptings of national ordinary and constitutional courts that move the Court of Justice to protect constitutional values over the primacy and autonomy of Union law. To this extent, national courts can be said to be guardians of constitutional values in Europe, to put it bluntly. Of course, saying that the national courts are the guardians of constitutionalism does not mean that one should be uncritical in this. To mention one problem: courts fundamentally lack some of the democratic essentials pertaining to parliaments. And it remains important to be aware of the fact that courts, in particular constitutional courts, can both act to protect democratic decision-making - democracy in the more restricted sense of protecting parliaments against undue executive dominance and in the broader sense of the rights essential for democracy to function (freedom of expression, association, academic freedom, separation of powers, etc.) - but also frustrate democratic decision-making to a larger or smaller extent. ${ }^{28}$

If, with this important caveat, we say that national courts often are the guardians of constitutionalism in Europe; and if we notice the wavering line of case of the Court of Justice, the question arises when might the time come when we can say more unreservedly that the Court is the guardian of constitutionalism? Does the way in which it engages with the independence of the judiciary in cases

\footnotetext{
${ }^{26}$ ECJ 4 May 1995, Case C-7/94, Gaal. It is not so much the judgment itself that is relevant, but a procedural incident in that case that triggered the Court's subsequent practice of publishing the composition of concrete chambers of the Court and assigning cases to it on the basis of more neutral criteria, thus complying minimally to requirements that the German constitutional case law sets for access to an independent court (Art. $101 \mathrm{GG}$, the right to one's gesetzliche Richter).

${ }^{27}$ ECJ 9 November 2010, Case C 92/09, Schecke and Eifert.

${ }^{28}$ As for instance the $B V \operatorname{erf} G$ s freezing of democratic debate over the future of European integration with its stringent views on its constitutional limits. For a theoretical and empirical analysis, see N.J. de Boer, Judging European Democracy: National Constitutional Review of European Law and Its Democratic Legitimacy (dissertation University of Amsterdam 2018).
} 
like Associação Sindical dos Juizes Portugueses ${ }^{29}$ and L.M. (better known as Celmer) ${ }^{30}$ mark a turning point in the European Court of Justice's full embrace of constitutionalism? And will it soon become so broad as embracing constitutionalism to the full, or remain limited to an understanding of 'the rule of law' that is limited to the role of courts only?

${ }^{29}$ ECJ (Grand Chamber) 27 February 2018, Case C-64/16, Associação Sindical dos Juizes Portugueses v Tribunal de Contas; see M. Bonelli and M. Claes, 'Judicial serendipity: how Portuguese judges came to the rescue of the Polish judiciary', 14(3) EuConst (2018) p. 622.

${ }^{30}$ ECJ 25 July 2018, Case C-216/18 PPU, The Minister for Justice and Equality v LM; see M. Krajewski, 'Who is Afraid of the European Council? The Court of Justice's Cautious Approach to the Independence of Domestic Judges in Case C-216/18 PPU The Minister for Justice and Equality v LM', 14(4) EuConst (2018) p. 792. 